\title{
Comparison of non-invasive and invasive blood pressure measurements in horses during anaesthesia using the oscillometric blood pressure monitor S/5 Datex Ohmeda
}

\author{
Nathalie Fouchél, Ulrike Aver², Isabelle Iff ${ }^{3}$ \\ 1 Swiss Institute of Equine Medicine (ISME), Vetsuisse-Faculty, University of Bern and Agroscope, Switzerland \\ ${ }^{2}$ Clinic for Anaesthesiology and perioperative Intensive Care, Veterinary University Vienna, Austria (Institute at which the work has been conducted) \\ 3 Veterinary Anaesthesia Services- International, Winterthur, Switzerland
}

\begin{abstract}
Summary: The purpose of this study was to assess the performance of indirect blood pressure measurements with an oscillometric blood pressure monitor ( $S / 5$, Datex-Ohmeda) in anaesthetized horses. The study was conducted as a prospective experimental study. Seven adult horses, five geldings and two mares, were used in this study. The average age was $15 \pm 8$ years (mean \pm SD) and the horses were weighing between 485 and $654 \mathrm{~kg}$. Invasive and non-invasive blood pressure measurements were recorded simultaneously and a total of 263 values were analyzed. The number of measurements obtained in each horse depended on the anaesthesia time (104-225 minutes). Bland and Altman analysis for repeated measurements was used for assessment of the data. Overall the most accurate measurement was achieved with mean arterial pressure (MAP) measurement with a bias of $5 \mathrm{mmHg}$ compared to a bias of $7 \mathrm{mmHg}$ in the systolic arterial pressure (SAP) and of $9 \mathrm{mmHg}$ in the diastolic arterial pressure (DAP). The MAP proved to be the most precise in the low arterial blood pressure group $(3 \mathrm{mmHg})$ followed by the medium arterial blood pressure group $(5 \mathrm{mmHg})$. These results show that non-invasive blood pressure measurements with Datex Ohmeda ( $\mathrm{S} / 5$, Datex-Ohmeda, $\mathrm{S} / 5^{\mathrm{TM}}$ Collect, Datex-Ohmeda) monitoring can be an adequate alternative to measure blood pressure in anaesthetized horses when invasive blood pressure measurement cannot be performed. Besides monitoring of anaesthesia, non-invasive blood pressure measurement can be very helpful in alert horses due to its non-stressful and non-invasive nature. Further comparable projects are required in awake patients and data collected in this study could serve as a basis for that.
\end{abstract}

Keywords: horse, anaesthesia, blood pressure measurement, oscillometric blood pressure monitor, Datex Ohmeda

Citation: Fouché N., Auer U., Iff I. (2016) Comparison of non-invasive and invasive blood pressure measurements in horses during anaesthesia using the oscillometric blood pressure monitor S/5 Datex Ohmeda. Pferdeheilkunde 32, 479-484

Correspondence: Dr. Isabelle Iff, Veterinary Anaesthesia Services-International, Zuercherstrasse 39, 8400 Winterthur, Switzerland; e-mail: isabelle.iff@vas-int.com

\section{Introduction}

Veterinarians performing anaesthesia in horses are often confronted with hypotension in the horses during surgery. This may be due to health or hydration status of the animal as well as anaesthetic drugs resulting in cardiovascular depression or vasodilation. Hypotension is a well-known reason for postoperative myopathy in horses. Therefore arterial blood pressure should always be monitored closely during anaesthesia and maintained at a reasonable level. For an experienced anaesthetist in an environment with the appropriate equipment, direct blood pressure measurement in the facial or the metatarsal artery is the clinical standard method. Nevertheless non-invasive blood pressure measurement can be required occasionally and knowledge about its reliability is necessary. Certain hospitals may not be able to afford the more expensive technical equipment required for invasive blood pressure monitoring or the expertise for intra-arterial cannulation is lacking. The non-invasive blood pressure measurement allows the initiation of dobutamine therapy under control until placement of the catheter is completed. In an awake horse invasive blood pressure measurement, although more accurate, can be difficult to perform and maintenance of the catheter remains challenging. Non-invasive blood pressure measurement can give an idea about the animals' status without stressing the animal. Several studies compared invasive and non-invasive blood pressure measurement in horses using different equipment (Muir et al. 1983, Franco et al.
1986, Giguere et al. 2005). The objective of this study was to assess the performance of non-invasive blood pressure measurements with Datex-Ohmeda S5 monitoring under clinical conditions.

\section{Materials and Methods}

Seven adult horses, five geldings and two mares, were used in this study. The study was conducted in conjunction with an experimental study on neuromuscular blocking agents. The average age was $15 \pm 8$ years and the horses were weighing 485 to $654 \mathrm{~kg}$. All horses were considered healthy at the physical examination and blood haematology and chemistry.

Prior to anaesthesia an intravenous catheter (Intraflon 2, 12 G, 1, Vygon Vet, Vygon (UK) Ltd, Swindon, Wiltshire, United Kingdom) was placed in the jugular vein under aseptic conditions for the administration of drugs and fluids.

The horses were sedated intravenously with $1 \mathrm{mg} / \mathrm{kg}$ xylazine (Xylapan, Vétoquinol AG, Ittigen, Switzerland) and anaesthesia was induced after five minutes with $25 \mathrm{mg} / \mathrm{kg}$ Thiopental (Thiopental Sandoz, Kundl, Austria). After endotracheal intubation the horses were positioned on the surgical table in left lateral recumbency and anaesthesia was maintained with Isoflurane (Isoflo, Richter Pharma AG, 4600 Wels, Austria) in 
oxygen. Depth of anaesthesia was monitored by clinical parameters (eyelid reflexes, nystagmus, heart rate and respiratory pattern) and isoflurane concentration was adapted as required by each individual animal. Routine monitoring included ECG, haemoglobin oxygen saturation, temperature and endtidal gas concentrations. Mechanical ventilation was used maintaining end-tidal $\mathrm{CO}_{2}$ between 6.0 and $7.5 \mathrm{kPa}$. dobutamine (Dobutamin, Solvay-Pharma Gesellschaft M.B.H., Wien, Austria) was administered as a constant infusion rate if required to maintain the invasive mean arterial blood pressure over $70 \mathrm{mmHg}$. At the end of anaesthesia the horses were moved into a padded box for recovery.

All animals received repeated injections of vecuronium (Norcuron, Organon $\mathrm{GmbH}$, Wien, Austria) and the evaluation of the neuromuscular blockade was made using "train-of-four" (TOF) stimulation.

Blood pressure was monitored using two different methods: invasive and non-invasive measurement. For the invasive blood pressure measurement an arterial catheter (Vasocan Braunüle, 20 G, B.Braun Melsungen AG, Melsungen, Germany) was inserted in the transverse facial artery against the direction of the blood flow and connected to a pressure transducer through a non-distensible fluid line. A two-point calibration was performed on the transducer using an aneroid manometer prior to the experiment. Dynamic calibration was performed using the fast flush test and visual assessment of the curves. The transducer was fixed at the height of the horse's sternum and zeroed against atmospheric pressure. Systolic (SAP), diastolic (DAP) and mean arterial blood pressure (MAP) were recorded every five minutes, averaging the values over one minute.

For the non-invasive method the horse's tail was first measured using a measuring tape. An inflatable cuff was then placed around the unclipped tail over the middle coccygeal artery and connected to an oscillometric blood pressure monitor (S/5, Datex-Ohmeda, GE Healthcare, Little Chalfond, Buckinghamshire, United Kingdom).

Systolic, diastolic and mean blood pressure and the pulse rate of both measurements- invasive and non-invasive- were recorded simultaneously. All parameters were monitored and recorded using a multiparametric anaesthetic monitor (S/5, DatexOhmeda) and the corresponding software $\left(\mathrm{S} / 5^{\mathrm{TM}}\right.$ Collect, Datex-Ohmeda, GE Healthcare, Little Chalfond, Buckinghamshire, United Kingdom). The data was evaluated for technical failures and erroneous measurements were excluded.

Statistical analysis was performed with MedCalc for Windows (Version 10.1 .0.0, MedCalc Software, Mariakerke, Belgium).
Agreement between the measurements of SAP, DAP and MAP overall as well as in the three pressure groups from the two measurement sites were evaluated using a method described by Bland and Altmann (1986) and adjustments were made for repeated measurements. The bias as well as the limits of agreement was calculated for invasive and non-invasive SAP, MAP and DAP measurements.

The heart rate (by ECG) and pulse rate (by invasive and noninvasive method) were compared. In 29 cases the pulse rate differed more than 10\% from the heart rate. Those measurements were excluded and statistical analysis of the remaining 234 pairs was compared to the previous results. Blood pressure values were divided into three groups according to a mean arterial pressure of less than $70 \mathrm{mmHg}$ (low), $71-100 \mathrm{mmHg}$ (medium) and more than $101 \mathrm{mmHg}$ (high). Additionally, individual bias was calculated for each horse using Excel and compared to the cuff-sternum distance. Accuracy of the non-invasive method compared to the tail circumference/cuff width ratio was evaluated in all three pressure groups.

\section{Results}

Duration of anaesthesia was between 104 and 225 minutes and all horses recovered from anaesthesia. The visual assessment of the curve after the fast flush tests did not reveal excessive over or under damping for the invasive blood pressure measurement.

A total of 289 pairs of invasive and non-invasive blood pressure measurements (SAP, DAP and MAP) was obtained. The number of measurements varied for each individual horse depending on the anaesthesia time (between 23 and 75 measurements). Twenty-six measurements were excluded due to technical failure. Reasons for exclusion were invalid reading of heart rate obtained by the ECG $(n=19)$ and technical failure of the oscillometric device $(n=7)$. Statistical analysis was performed on the remaining 263 measurements.

Within the 263 paired results MAP varied between 59 and $103 \mathrm{mmHg}$, SAP between 79 and $157 \mathrm{mmHg}$ and DAP between 43 and $84 \mathrm{mmHg}$ for the invasive measurement and MAP between 52 and $98 \mathrm{mmHg}$, SAP between 70 and $125 \mathrm{mmHg}$ and DAP between 34 and $81 \mathrm{mmHg}$ for the noninvasive measurement.

All Bland and Altman Results are reported as bias (upper and lower limits of agreement). Overall the non-invasive blood pressure measurement had a tendency to underestimate the invasive blood pressure. The most accurate measurement

Table 1 Overall results for the comparison of the non-invasive blood pressure measurements with invasive measurements with the Datex Ohmeda $\mathrm{S} / 5$.

\begin{tabular}{|c|c|c|c|c|}
\hline & SAP & DAP & MAP & \\
\hline Mean difference of paired readings (bias, accuracy) & 7 & 9 & 5 & $\mathrm{mmHg}$ \\
\hline SD of the difference (precision) & 11 & 5 & 5 & $\mathrm{mmHg}$ \\
\hline$\%$ Error ( $2 \times$ precision/mean) & 15 & 28 & 13 & $\%$ \\
\hline 95\% Lower limits of agreement & -13 & 0 & -5 & $\mathrm{mmHg}$ \\
\hline 95\% Upper limits of agreement & 27 & 17 & 14 & $\mathrm{mmHg}$ \\
\hline
\end{tabular}


was achieved with the MAP measurement bias $5 \mathrm{mmHg}$ (17, $-7 \mathrm{mmHg}$ ) compared to a bias of $7 \mathrm{mmHg}(29,-14 \mathrm{mmHg})$ in the SAP and of $9 \mathrm{mmHg}(19,-1 \mathrm{mmHg})$ in the DAP.

In 29 cases the pulse rate differed more than 10\% from the heart rate. Excluding those measurements resulted in a bias of $5 \mathrm{mmHg}(14,-5 \mathrm{mmHg})$ for the MAP measurements, of $7 \mathrm{mmHg}(27,-13 \mathrm{mmHg})$ for SAP and $8 \mathrm{mmHg}(17,0 \mathrm{mmHg})$ for DAP measurements.

The division into three pressure groups resulted in a very large group with a mean arterial blood pressure between 71 and $100 \mathrm{mmHg}(\mathrm{n}=230)$ and a smaller group with a mean arterial blood pressure $<70 \mathrm{mmHg}(\mathrm{n}=31)$. Only in two cases a mean arterial blood pressure over $101 \mathrm{mmHg}$ was measured and this group was not statistically analysed.

The most accurate results were obtained for the MAP measurements in the low arterial blood pressure group with a bias of $3 \mathrm{mmHg}(14,-9 \mathrm{mmHg})$. Bias of the MAP of the medium arterial blood pressure group was almost the same as for overall results $(5 \mathrm{mmHg}(14,-4 \mathrm{mmHg}))$. DAP measurement was more accurate in the low arterial blood pressure group (Bias of $6 \mathrm{mmHg}(13,-1 \mathrm{mmHg})$ compared to $9 \mathrm{mmHg}$ $(18,0 \mathrm{mmHg})$ in the medium arterial blood pressure group) whereas SAP was more accurate in the medium arterial blood pressure group (Bias of $7 \mathrm{mmHg}(26,-12 \mathrm{mmHg})$ compared to $10 \mathrm{mmHg}(35,-16 \mathrm{mmHg})$ in the low arterial blood pressure group).

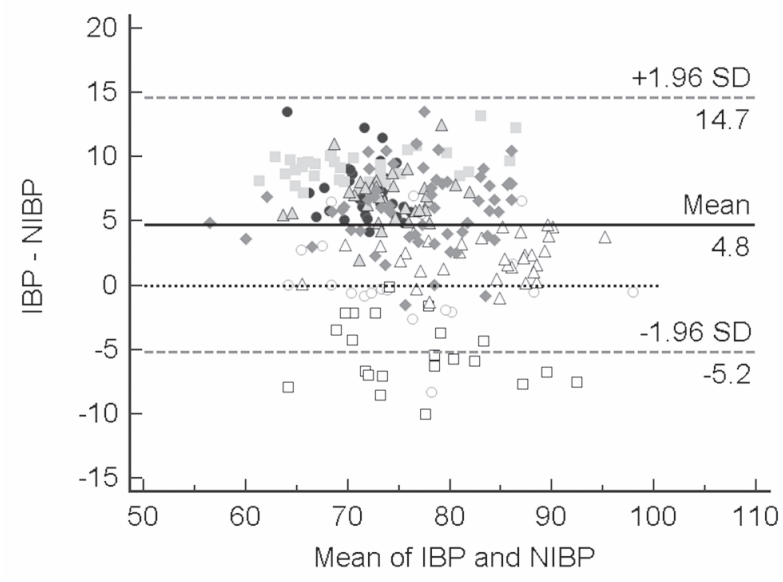

Fig. 1 Bland an Altman Graph for the comparison of invasive and non-invasive measurements differentiated according to the individual horse.
The values for each individual horse are presented in table 2. Looking at each individual horse bias of the MAP measurements (Fig. 1) shows that there is a relatively large inter-individual variability whereas the intra-individual variability is comparatively low. In one horse (number 3 ) the non-invasive measurement is clearly overestimating the MAP compared to the invasive measurement (bias $-5 \mathrm{mmHg}$ ). It is the horse that had the largest tail circumference of the group and therefore a relatively high tail circumference/ cuff-width ratio. All the non-invasive MAP measurements of the other horses had a tendency to underestimate the blood pressure compared to the invasive measurements.

The tail circumference of the horses varied between 22 and $25.5 \mathrm{~cm}$ whereas the cuff width was standardised in this study $(8 \mathrm{~cm})$. The average tail circumference/ cuff width ratio was $0.29(0.28-0.32)$ so the cuff width was around one-third of the tail circumference.

\section{Discussion}

Blood pressure measurements are widely used in human and veterinary medicine during anaesthesia or in awake patients (Muir et al. 1983, Franco et al. 1986, Giguere et al. 2005). Advantages and disadvantages of non-invasive blood pressure measurements have frequently been discussed in the scientific literature (Riebold and Evans 1985). Bailey et al found a large measurement error using indirect Doppler ultrasonic measurements in dorsally recumbent horses when compared to invasive systolic measurements (Bailey et al. 1994). Other techniques (auscultatory technique, use of an aneroid manometer and electronic sphygmomanometer, Doppler arterial blood pressure etc.) have been evaluated revealing various results concerning the reliability of the different methods in different species (Riebold and Evans 1985, Bailey et al. 1994). Oscillometric blood pressure measurement is commonly used in human and small animal medicine and several non invasive blood pressure monitors have been evaluated in standing or anaesthetised horses recently (Hatz et al. 2015, Tünsmeyer et al. 2015, Drynan et al 2016, Heliczer et al. 2016, Olsen et al. 2016)

In the present study, overall the non-invasive blood pressure measurement underestimated MAP, SAP and DAP compared to the invasive measurement. In the medical field, European recommendations define $5 \mathrm{mmHg}$ as very accurate, 6-10 $\mathrm{mmHg}$ as slightly inaccurate, $11-15 \mathrm{mmHg}$ as modera-

\begin{tabular}{|c|c|c|c|c|c|c|c|c|c|}
\hline Horse & age & weight & sex & S-T distance & $\mathrm{TC}$ & $\mathrm{TC} / \mathrm{C}$ & $\mathrm{N}$ & individual bias & individual precision \\
\hline & yrs & $\mathrm{kg}$ & & $\mathrm{cm}$ & $\mathrm{cm}$ & $\%$ & & $\mathrm{mmHg}$ & $\mathrm{mmHg}$ \\
\hline 1 & 9.5 & 489 & $\mathrm{mc}$ & 1 & 24.5 & 33 & 58 & 6 & 3 \\
\hline 2 & 19.5 & 544 & $\mathrm{mc}$ & -1 & 24 & 33 & 34 & 9 & 1 \\
\hline 3 & 28 & 566 & $\mathrm{mc}$ & 12 & 25.5 & 31 & 22 & -5 & 3 \\
\hline 4 & 9.25 & 485 & $f$ & 12 & 24.5 & 33 & 20 & 1 & 4 \\
\hline 5 & 18.5 & 510 & $f$ & NA & 22 & 36 & 33 & 7 & 2 \\
\hline 6 & 6.5 & 518 & $\mathrm{mc}$ & 9 & 23 & 35 & 34 & 2 & 2 \\
\hline 7 & 12.3 & 654 & $\mathrm{mc}$ & -2 & 24 & 33 & 33 & 7 & 2 \\
\hline
\end{tabular}

bias = mean of the difference between invasive and non-invasive measurements; precision= SD of the difference; $\mathrm{N}=$ number of measurements

$\mathrm{TC}=$ tail circumference; $\mathrm{TC} / \mathrm{C}=$ tail circumference/cuff width ratio; $\mathrm{S}-\mathrm{T}=$ sternum tail distance 
tely inaccurate and $>15 \mathrm{mmHg}$ as very inaccurate $\left(O^{\prime}\right.$ Brien et al. 2002). The oscillometric device used in this study would be considered very accurate for MAP and DAP and moderately inaccurate for SAP.

This is comparable to results of an early study where another monitor was evaluated in a similar study setting in horses (Branson 1997). The more recent studies using different oscillometric devices similarly showed an underestimation of MAP, SAP and DAP (Tünsmeyer et al. 2015, Drynan et al 2016, Heliczer et al. 2016, Olsen et al. 2016).

In the present study the most accurate measurement was the MAP with a bias of $5 \mathrm{mmHg}$, precision of $5 \mathrm{mmHg}$ an upper/lower limit of agreement of $17 \mathrm{mmHg} /-6 \mathrm{mmHg}$. Accuracy (bias) in the other oscillometric devices evaluated recently in anaesthetised horses ranged from $0.5-2 \mathrm{mmHg}$ for MAP, while precision (SD of the difference) ranged from 10-14 mmHg (Tünsmeyer et al. 2015, Drynan et al 2016, Heliczer et al. 2016). The two most common clinical settings where arterial blood pressure is measured are anaesthetised horses and standing, conscious horses with suspicion of hypertension. Whereas SAP is the clinically important value for conscious horses with hypertension, the most important clinical value to guide treatment of hypotension is MAP rather than SAP or DAP (Corley 2004). Recently, MAP in standing adult horses was found to be more accurate and precise than SAP or DAP and has been recommended for clinical decision making as well (Olsen et al. 2016).

Lack of agreement between methods could also be due to erroneous direct blood pressure measurements. The "gold standard" for invasive blood pressure recordings is the use of a micro transducer in the tip of an arterial catheter. In the clinical setting, invasive blood pressure measurement using a fluid-filled pressure transducer system is most commonly used. However, this method is not free from errors and when using invasive blood pressure measurement at different sites a significant difference was found in individual horses, but no significant difference when all horses were averaged (Parry et al. 1982). Over and underdamping and distortion of the signal are the most common factors influencing invasive pressure measurement. To minimise their influence a system with a natural frequency higher than the horses pulse rate was used to eliminate influence of resonance. Additionally short, non-compliant tubing was used, the system was flushed to eliminate visible air bubbles and a fast flush test was used to visually assess the system for over- or underdamping. The SAP and DAP are the main pressures influenced by damping of the system, and this might explain greater inaccuracy seen in those two values.

Clinicians are mostly used to monitor and interpret systolic, diastolic and mean arterial blood pressure measured directly in the facial or metatarsal artery so we considered it more useful in a clinical context to compare those values to the non-invasive measurement instead of comparing direct and indirect measurements of the middle coccygeal artery.

To improve accuracy in the clinical setting it is commonly recommended to disregard any blood pressure measurements, where the heart rate measured by the blood pressure monitor differs from the actual heart rate of the animal. In this study 29 non-invasive blood pressure measurements showed a difference of more than $10 \%$ between heart rate compared to the rate assessed by ECG. When these measurement pairs were excluded from the analysis the Bias differed only by $1-2 \mathrm{mmHg}$ for the overall results of SAP, MAP and DAP.

Furthermore, the accuracy of a non-invasive pressure monitor also largely depends on body position and cuff placement site and for two oscillometric NIBP monitors the use of the tail for animals in lateral recumbency has been recommended (Hatz et al. 2014, Tearney et al. 2016).

The cuff sternum-difference was measured in these horses and ranged from -2 to $12 \mathrm{~cm}$. In the medical literature, a "correction" factor of $0.77 \mathrm{mmHg} / \mathrm{cm}$ of vertical distance between the cuff site and the base of the heart is used. It has been described similarly in horses (Parry et al. 1984), but it has not been validated in this species. To reflect the clinical use of the device the authors elected not to apply a correction factor.

In the medical literature, the main source of failure/inaccuracy for indirect blood pressure measurement remains the correct choice of the cuff size. In horses this has been described as well, with narrower cuffs resulting in an overestimation of blood pressure and wider cuffs resulting in an underestimation of blood pressure (Taylor 1981). However, recommendations for cuff sizes vary. One study determined optimum cuff width for indirect blood pressure measurements to be about one-fifth of the tail circumference (Latshaw et al. 1979), while others recommended ratios of 0.35 (Muir et al. 1983) and 0.25 (Geddes et al. 1977), respectively. A recent study recommends a cuff with a ratio of 0.25 at the tail to provide the most accurate results when compared to invasive measurements (Tearney et al. 2016).

In the study presented here, the cuff width was about onethird of the tail circumference. According to the aforementioned study this lies in between different recommendations. Parry et al. compared the optimum bladder width (BW)/ tail girth (TG) ratios for systolic and for diastolic blood pressures. The optimum BW/TG ratios for unclipped tails were 0.296 for systolic blood pressure and 0.866 for diastolic blood pressure (Parry et al. 1982). In the horses of the presented study the mean BW/TG ratio was 0.29 .

Non-invasive blood pressure measurements with Datex Ohmeda (S/5) with the cuff placed at the tail in horses in lateral recumbency provides readings with acceptable accuracy and precision, when looking at mean arterial pressures in anaesthetized horses. Systolic and diastolic pressure measurements showed less accuracy and precision. The pressure range evaluated in this study was from $79-159 \mathrm{mmHg}$ for SAP, 43-84 mmHg for DAP and 59-103 $\mathrm{mmHg}$ for MAP. Inter-individual differences in bias exist and possible inaccurate readings need to be taken into account for clinical decision-making.

\section{Animal welfare statement}

The study has been approved by the Ethical Committee of the University of Veterinary Medicine of Vienna in Austria and had governmental approval. Reference number 68.205/0218Il/10b/2009 


\section{Conflict of Interest}

None of the authors has an affiliation with the company nor as has received sponsorship or loan of the technical device used in this study.

\section{References}

Bailey J. E., Dunlop C. I., Chapman P. L., Demme W. C., Allen S. L., Heath R. B., Crump K. T., Golden C. S., Wagner A. E. (1994) Indirect Doppler ultrasonic measurement of arterial blood pressure results in a large measurement error in dorsally recumbent anaesthetised horses. Equine Vet. J. 26, 70-73

Bland J. M., Altman D. G. (1986) Statistical methods for assessing agreement between two methods of clinical measurement. The Lancet 1, 307-310

Branson K. R. (1997) A clinical evaluation of an oscillometric blood pressure monitor on anaesthetized horses. Equine Vet. Sci. 17, 537-540

Corley K. T. (2004) Inotropes and vasopressors in adults and foals. Vet. Clin. North Am. Equine Pract. 20, 77-106

Drynan E. A., Schier M., Raisis A. L. (2016) Comparison of invasive and noninvasive blood pressure measurements in anaesthetized horses using the Surgivet V9203 Vet. Anaesth. Analg. 43, 301-308

Franco R. M., Ousey J. C., Cash R. S., Rossdale P. D., Silver M. (1986) Study of arterial blood pressure in newborn foals using an electronic sphygmomanometer. Equine Vet. J. 18, 475-478

Geddes L. A., Chaffee V., Whistler S. J., Bourland J. D., Tacker W. A. (1977) Indirect mean blood pressure in the anesthetized pony. Am. J. Vet. Res. 38, 2055-2057

Giguere S., Knowles H. A., Jr., Valverde A., Bucki E., Young L. (2005) Accuracy of indirect measurement of blood pressure in neonatal foals. J. Vet. Intern. Med. 19, 571-576

Hatz L. A., Hartnack S., Kümmerle J., Hässig M., Bettschart-Wolfensberger R. (2014) A study of measurement of noninvasive blood pressure with the oscillometric device, Sentinel, in isoflurane- anaesthetized horses. Vet. Anaesth. Analg. 42, 396-376

Heliczer N., Lorello O., Casoni D., Navas de Solis C. (2016) Accuracy and Precision of Noninvasive Blood Pressure in Normo-, Hyper-, and Hypotensive Standing and Anesthetized Adult Horses. J. Vet. Int. Med. 30, 866-872

Latshaw H., Fessler J. F., Whistler S. J., Geddes L. A. (1979) Indirect measurement of mean blood pressure in the normotensive and hypotensive horse. Equine Vet. J. 11, 191-194

Muir W. W., Wade A., Grospitch B. (1983) Automatic noninvasive sphygmomanometry in horses. J. Am. Vet. Med. Assoc. 182, 1230-1233

O'Brien E., Pickering T., Asmar R., Myers M., Parati G., Staessen J., Mengden T., Imai Y., Waeber B., Palatini P., Gerin W. (2002) Working Group on Blood Pressure Monitoring of the European Society of Hypertension Inter- national Protocol for validation of blood pressure measuring devices in adults. Blood Press Monit. 7, 3-17

Olsen E. Skovgaard Pedersen T. L., Robinson R., Andersen P. H. (2016) Accuracy and precision of oscillometric blood pressure in standing conscious horses. Vet. Emerg. Crit. Care 26, 85-92

Parry B. W., McCarthy M. A., Anderson G. A., Gay C. C. (1982) Correct occlusive bladder width for indirect blood pressure measurement in horses. Am. J. Vet. Res. 43, 50-54

Riebold T., Evans A. (1985) Blood pressure Measurements in the Anaesthetized Horse Comparison of Four Methods. Vet. Surg. 14, 332-337

Taylor P. M. (1981) Techniques and clinical application of arterial blood pressure measurement in horse. Equine Vet J 13, 271-275

Tearney C. C., Guedes A. G. P., Brosnan R. J. (2016) Equivalence between invasive and oscillometric blood pressures at different anatomic locations in healthy normotensive anaesthetised horses. Equine Vet. J. 2015. doi:10.1111/evj.12443
Tünsmeyer J., Hopster K., Feige K., Kästner S. B. R. (2015) Agreement of high definition oscillometry with direct arterial blood pressure measurement at different blood pressure ranges in horses under general anaesthesia. Vet. Anaesth. Analg. 42, 286-291

Erweiterte Zusammenfassung

Vergleichsstudie nicht-invasiver und invasiver Blutdrukkmessungen bei anästhesierten Pferden mit dem oszillometrischen Blutdruckmonitor des S/5 Datex Ohmeda

Anästhetika können bei Pferden häufig eine Hypotension bewirken, die für Morbidität und sogar Mortalität verantwortlich sein kann. Deshalb sollte der arterielle Blutdruck überwacht und gegebenenfalls mit pharmakologischen Methoden unterstütz† werden. Für erfahrene Anästhesisten in einer Klinik mit der entsprechenden Ausrüstung ist die direkte, invasive Blutdruckmessung in einer Arterie des Gesichts oder den Beinen Standard. Trotzdem kann nicht-invasive Blutdruckmessung manchmal nötig sein und die Verlässlichkeit eines nichtinvasiven Blutdruckmonitors sollte immer überprüft werden. Ziel dieser Studie war die Ermittlung der Messgenauigkeit nicht-invasiver oszillometrischer Blutdruckmessungen mit Hilfe des Datex-Ohmeda-Monitors S/5 im Vergleich zu invasiver Blutdruckmessung. Es handelt sich um eine prospektive Studie, die bei anästhesierten Pferden durchgeführt wurde.

Insgesamt wurden 7 gesunde Pferde untersucht. Die 2 Stuten und 5 Wallache waren durchschnittlich $15 \pm 8$ Jahre alt (Mittelwert \pm Standardabweichung) und wogen zwischen 485 und $654 \mathrm{~kg}$. Alle Pferde zeigten bei einer klinischen Untersuchung, sowie einer Evaluation der Blutchemie und Hämatologie normale Werte. Allen Pferden wurde vor der Anästhesie ein venöser Zugang in der V. jugularis zur Verabreichung von Medikamenten und Flüssigkeit gelegt. Die Pferde wurden mit Xylazin (Xylapan, Vétoquinol AG, Ittigen, Schweiz) prämediziert. Die Anästhesie wurde mit Thiopental (Thiopental Sandoz, Kundl, Österreich) eingeleitet. Zur Aufrechterhaltung der Anästhesie erhielten die Pferde Isofluran (Isoflo, Richter Pharma AG, 4600 Wels, Österreich) in Saverstoff über einen Tracheotubus. Nach der endotrachealen Intubation wurden die Pferde auf einem gepolsterten Tisch in Seitenlage gelagert.

Klinische Parameter zur Feststellung der Anästhesietiefe (Lidreflex, Nystagmus, Herzfrequenz und Atemmuster), sowie Herzfrequenz und -rhythmus durch ein Elektrokardiogramm (EKG), periphere Sauerstoffsättigung, Temperatur und endexspiratorische Atemgasmessungen dienten der Überwachung der Patienten während der Anästhesie. Die Ventilation wurde, falls indiziert durch mechanische Beatmung unterstütz† um den end-tidalen $\mathrm{CO}_{2}$ zwischen 6.0 und $7.5 \mathrm{kPa}$ zu halten. Zur Erhaltung des mittleren invasiv gemessenen Blutdrucks über $70 \mathrm{mmHg}$ erhielten die Pferde Dobutamin (Dobutamin, Solvay-Pharma Gesellschaft M.B.H., Wien, Österreich) in einer Davertropfinfusion.

Es wurden gleichzeitig invasive und nicht-invasive Blutdrukkmessungen durchgeführt und aufgezeichnet. Für die invasive Blutdruckmessung wurde ein Venenkatheter (Vasocan Braunüle, 20 G, B.Braun Melsungen AG, Melsungen, Deutschland) in die Arteria transversa faciei entgegen der Richtung des Blutflusses gelegt. Der Katheter wurde über eine Drucklei- 
tung an einen elektronischen Druckwandler angeschlossen, welcher mit einem Monitor (S/5, Datex-Ohmeda, GE Healthcare, Little Chalfond, Buckinghamshire, Grossbritannien) verbunden war. Der Druckwandler wurde auf Höhe des Sternums positioniert und auf den Athmosphärendruck genullt. Die Distanz zwischen dem Schweif und der Sternumhöhe wurden gemessen. Eine Zwei-Punkte-Kalibration mit einem aneroiden Manometer und eine dynamische Kalibrierung mittels eines „Fast-Flush-Tests" wurde vor der Messung durchgeführt. Der systolische (SAP), diastolische (DAP) und mittlere Blutdruck wurde alle 5 Minuten gemessen, wobei jeweils der Durchschnittswert der Messungen während einer Minute aufgezeichnet wurde. Für die nicht-invasive Blutdruckmessung wurde der Schweifumfang der Pferde gemessen. Die Manschette wurde am ungeschorenen Schweif über der Arteria coccygea mediana angebracht und mit dem Monitor (S/5, Datex-Ohmeda, GE Healthcare, Little Chalfond, Buckinghamshire, Grossbritannien) verbunden. Die Grösse der Manschette betrug bei allen Pferden $8 \mathrm{~cm}$. Die Werte für SAP, DAP und MAP, sowie die Herzfrequenz und die Pulsfrequenz wurden gleichzeitig aufgezeichnet und mit der zugehörigen Software $\left(\mathrm{S} / 5^{\mathrm{TM}}\right.$ Collect, Datex-Ohmeda, GE Healthcare, Little Chalfond, Buckinghamshire, Grossbritannien) aufgezeichnet. Die Daten wurden für technische Fehler überprüft und ungültige Messungen wurden vor der Evaluation ausgeschlossen.

Der Unterschied der Herzfrequenz (EKG) und der Pulsfrequenz (invasive und nicht-invasive Blutdruckmessung) wurde verglichen und der Unterschied in Prozent errechnet. Die statistische Auswertung wurde mit MedCalc für Windows (Version 10.1.0.0, MedCalc Software, Mariakerke, Belgien) durchgeführt. Zum Vergleich der Messmethoden wurde das Verfahren nach Bland und Altman angewendet und als Bias (Mittelwert der Differenz zwischen der invasiven und der nichtinvasiven Messung) und Limits of Agreement präsentiert. Die Resultate wurden für wiederholte Messungen berichtigt. Die Ergebnisse wurden für alle Messungen insgesamt evaluiert. Zusätzlich wurden die Werte anhand des mittleren invasiven Blutdruckes in 3 Gruppen (niedrig, normal, hoch) geteilt und diese Gruppen separat ausgewertet. Zusätzlich wurde mit Excel ein individueller Bias für jedes Pferd errechnet, dieser Bias wurde mit der Schweif-Sternum-Distanz und mit dem Verhältnis von Schweifumfang/Manschettenbreite verglichen.

Die Zahl der Messungen pro Pferd (zwischen 23 und 75 Messungen) hing von der Anästhesiedaver ab (zwischen 104 und 225 Minuten). Insgesamt wurden 289 Datenpaare zum Vergleich aufgezeichnet, wovon 263 analysiert wurden. Ausschlussgründe waren eine fehlerhafte Aufzeichnung des EKG in 19 Fällen und mangelhaftes Funktionieren der nicht-invasiven Blutdruckmessung in 7 Fällen. Die Auswertung der 263 Messungen ergab einen mittleren Blutdruck von 59 bis $103 \mathrm{mmHg}$, einen systolischen Blutdruck von 79 bis $157 \mathrm{mmHg}$ und einen diastolischen Blutdruck von 43 bis $84 \mathrm{mmHg}$ mittels der invasiven Blutdruckmessung und einen mittleren Blutdruck von 52 bis $98 \mathrm{mmHg}$, einen systolischen Blutdruck von 70 bis $125 \mathrm{mmHg}$ und einen diastolischen Blutdruck von 34 bis $81 \mathrm{mmHg}$ mittels der nicht-invasiven Messmethode. Insgesamt hat die nicht-invasive Blutdruckmessung, tendenziell niedriger gemessen, als die invasive Blutdruckmessung.
In 29 Messungen unterschied sich die Pulsfrequenz des nichtinvasiven Blutdruckes um mehr als 10\% von derjenigen der invasiven Blutdruckmessung. Nach Ausschluss dieser Messpaare resultierte ein Bias von $5 \mathrm{mmHg}(14,-5 \mathrm{mmHg})$ für den MAP, $7 \mathrm{mmHg}(27,-13 \mathrm{mmHg})$ für SAP und $9 \mathrm{mmHg}$ (17, $0 \mathrm{mmHg}$ ) für DAP Messungen.

Die Unterteilung in 3 Blutdruckgruppen, basierend auf dem mittleren invasiven Blutdruck ergab eine sehr große Gruppe mit einem MAP von 71 bis $100 \mathrm{mmHg}(n=230)$ und eine kleinere Gruppe mit MAP $<70 \mathrm{mmHg}(n=31)$. Nur zwei Fälle hatten einen MAP $>101 \mathrm{mmHg}$ und diese Gruppe wurde statistisch nicht analysiert. Die besten Resultate wurden für den MAP in der Gruppe "niedriger Blutdruck" mit einem Bias von $3 \mathrm{mmHg}(14,-9 \mathrm{mmHg})$ erzielt. Die Resultate der Gruppe "normaler Blutdruck" waren ähnlich mit einem Bias von $5 \mathrm{mmHg}(14,-4 \mathrm{mmHg})$. DAP Messungen waren genauer in der Gruppe "niedriger Blutdruck" Bias of $6 \mathrm{mmHg}$ (13, - $1 \mathrm{mmHg}$ ) verglichen mit $9 \mathrm{mmHg}(18,0 \mathrm{mmHg})$ in der Gruppe "normaler Blutdruck" und SAP war genauer in der Gruppe "normaler Blutdruck" (Bias von $7 \mathrm{mmHg}(26,-12 \mathrm{mmHg})$ verglichen mit der Gruppe "niedriger Blutdruck" 10 mmHg (35, $-16 \mathrm{mmHg})$ ).

Bei der Betrachtung der einzelnen Pferde wurde festgestellt, dass eine große inter-individuelle Variabilität, jedoch eine kleine intra-individuelle Variabilität besteht (Fig. 1). Die MAP Messungen hatten außer bei einem einzelnen Pferd immer die Tendenz, den invasiven Blutdruck zu unterschätzen. Dieses Pferd (Nr. 3) zeigt eine Überschätzung des invasiven Blutdrukks durch die nicht-invasive Messung von gemittelt $5 \mathrm{mmHg}$. Das Pferd hatte den größten Schweifumfang und deshalb eine großes Verhältnis des Schweifumfangs zur Manschettenbreite.

Der Schweifumfang betrug zwischen 22 and $25.5 \mathrm{~cm}$. Mit der festgelegten Manschettenbreite von $8 \mathrm{~cm}$ betrug das Verhältnis von Schweifumfang zur Manschettenbreite bei diesen Pferden 0.29 (0.28-0.32), somit etwas weniger als ein Drittel.

\section{Schlussfolgerung}

Die nicht-invasive Blutdruckmessung mit dem Datex Ohmeda (S/5) mit der Manschette am Schweif und den Tieren in Seitenlage ergab eine klinisch akzeptable Genauigkeit und Präzision zur Evaluierung des mittleren Blutdrucks bei anästhesierten Pferden. Die systolische und diastolische Druckmessung mit der invasiven Methode zeigten weniger Messgenauigkeit und Präzision. Der Mittlere Blutdruck bei den klinischen Patienten lag zwischen 59-103 mmHg, der systolische zwischen $79-159 \mathrm{mmHg}$ und der diastolische zwischen 43-84 mmHg. Ein inter-individueller Unterschied in der Messgenauigkeit ist deutlich sichtbar und mögliche Falschmessungen sollten bei der klinischen Verwendung in Betracht gezogen werden.

Schlüsselwörter: Pferd, Anästhesie, Blutdruckmessung, oszillometrische Blutdruckmessung, Datex Ohmeda 